\title{
Age Related Techniques in Teaching and Speaking a Foreign Language
}

\author{
Daniela Gordi (Dilo)
}

\section{ABSTRACT}

\begin{abstract}
The purpose of this article is to show the importance of age related techniques used in classes that help students enjoy, learn and speak a foreign language. There are different techniques used at different ages. However, it is also important to build a good relationship and in order to do so, teacher must know his/her students' goals, age, foreign language level, interests and background and furthermore real practice of lesson topics. Most importantly, what we teach should relate to students. Creating a good atmosphere is important. There are some difficulties to improve all skills of speech activity at the same time. Teachers should find the right tools and strategies adopted to every age. Role playing, debating, reading, asking the right questions are some important tools.
\end{abstract}

Keywords: atmosphere, age techniques, difficulties, language.
Published Online: August 21, 2021

ISSN: $2736-4534$

DOI : $10.24018 /$ ejedu.2021.2.4.151

\section{Daniela Gordi (Dilo)}

Faculty of Foreign Languages,

University of Tirana, Tirana, Albania.

(e-mail: danieladilo@yahoo.com)

*Corresponding Author

\section{INTRODUCTION}

Learning a Foreign Language nowadays is becoming popular due to globalization. To learn a foreign language is not only about speaking a new language, but also learning about a different culture and it is surely a way to become an open-minded, understanding, tolerant individual. That is one of the reasons why foreign languages, especially English is taught from young age nowadays. Parents want their children to be prepared for a world, which is changing quickly. They want their children to see the world from a different perspective. It is well known that foreign languages are taught according to different principles, methods, and skills. First, the learning methods are chosen based on their age and interests. As we know there are four important sections in foreign languages: speaking, reading, listening, and writing. Our job as a teacher is to find the right methods to teach these skills. The final goal is to prepare our students for real life communication.

Rebecca L. Oxford stated that students of different ages and learning stage of second language employed somewhat different strategies; older or more advanced students used certain strategies more frequently than did younger or less advanced students [1].

The types of abilities Linguists divide language learning into four major parts:

- Reading is the ability to read a foreign language;

- Listening is the comprehension of a foreign language text;

- Writing is ability to write in a foreign language;

- Speaking is the ability to speak in a foreign language.

To achieve these four things, it is important to master three things: grammar, vocabulary, and pronunciation. This means that learning a foreign language is much more difficult without mastering these three things. However, is it always easy to teach these skills with all ages? We as teachers should adjust the right techniques according to their age.

\section{OBJECTIVES}

- To identify techniques to teach a foreign language suited for every age group.

- To motivate and encourage students learning a foreign language.

- To make students feel comfortable and speak freely in a foreign language.

- To identify factors that encourage or stop students from performing well in a class.

\section{Teaching Students Age 5-7}

As we mentioned it is important that the teachers should adjust the activities to the age of students. It would be easier for them to do activities appropriate to their age and they would feel motivated. Since in this age group there could still be pupils that have not mastered the writing skill, teachers should try to adapt the curriculum and classes, first, to the abilities and knowledge of such young learners. This means that most of the learning will take place through games that are already familiar to them. At this age, children learn the first words in English. At the same time, they have fun through interesting activities and play, get to know the sounds of a new language and develop curiosity and listening skills. The use of flashcards, songs, DVD's are important tools at this age. We can encourage them to express themselves through painting and drawing at this age. They can talk about themselves say, what they love doing for example:

I am.... 
I come from....

I like...

They illustrate their thoughts through paintings, and they get to know each other better. Learning songs, rhymes, fairytales bring a nice atmosphere and encouraging one. They awaken children's curiosity and encourage them to learn new words and simple sentences. In addition, children use receptive strategies such as repetition and memorization first. Then they develop strategies permitting them to start and maintain interactions. We cannot teach grammar children at this age but by repetition of certain structures, they learn it naturally.

\section{TEACHING STUdents AgE 7-10}

For students at this age is important to find topics that are close to students, that is, those that will stimulate interest so that they will be relatively easy to master. Apart from the fact that the students at this age should learn how to communicate properly in the foreign language, and at their level of knowledge, team spirit will develop, since it is best that the teaching be as interactive as possible. That is why roleplaying is essential. For example, they may assume they have a problem with the parents, so one will become the parent and the other the child, or a problem between friends. Students are familiar with these problems and so they will have no difficulty in choosing vocabulary. However, we can help them by writing a list of words on the board that they can use. Another method is to discover something in which students are talented such as, cooking, acting, painting etc. These kinds of activities give themselves confidence and encourage their speaking skills but also the usage of grammatical skills. The role of the teachers is to encourage them to do things that interest them, certainly to that level. Therefore, they need to feel confident and express their opinion. So, creating a positive atmosphere, one in which children are encouraged to think freely plays a major role.

"There are always ideas that make others laugh. If we think freely, outside the frames, brilliant ideas can come to us [2]."

Learning a language is an ongoing process. The main task of a teacher is to arouse interest and encourage students to learn independently.

\section{Teaching Students Age 11-14}

Children aged 11 to 14 should already have a certain level of knowledge of the English language, and the teacher should determine what these skills are, but also perfect them in a way that they follow the school's curriculum as closely as possible. The curriculum should also be adjusted to the students' interests in order to hold the students' attention during lessons, and through the practice of all language skills, (writing, reading, listening and conversation), students will get the necessary security in the knowledge they have acquired. One of the strategies that I find the most productive when it comes to speaking is brainstorming.

This is known as one of the most powerful techniques. Brainstorming is an idea that produces techniques. Technique that takes ideas. "His goals are (1) to separate us from our thinking habits, (2) to produce a set of ideas where we can choose [3].

This technique can be done individually or in a group of 2 to 10 people. Furthermore, versatility in class activities will not only help with mastering all language skills, but it will awaken the interest in students to learn more and they will be less likely to get bored during the classes because they will be more interesting. The usage of all the skills is important at this age. At this age children are capable of learning grammatical structures, pronunciation.

\section{Teaching Students AgES 15 TO 18}

$\mathrm{T}$ One of the activities that I prefer mostly for this age group is debating. Why does it work? Debate encourages students to think about many sides of an issue and makes them interact. They exchange their thoughts, deepen their thoughts, reflect, and learn to listen to others.

"Teachers can help develop critical thinking through discussions where the teacher plays the role of facilitator [4]."

Debates for example about different topics not only encourage them to talk but also develop critical thinking also. The teacher in this process is the facilitator. Teachers have to choose the topics related to their student's interests. Then they are divided into groups. They have to give and support their ideas, giving their arguments. The role of the teachers in the end is to make a summary of their strong and weak points. A major barrier to speaking is prejudice. We all have prejudices because we have different ideas about what is true, false, wrong, and right. Our prejudices relate to patriotism, race, gender, class, and the way we think.

"Being a critical thinker does not mean that you have no thoughts, but that you are resilient to ideas and can change your mind. Foreign language teachers should always be aware of the data, information, and evidence to answer prejudices. This is the main rule: when ideas are thrown in, critical comments are not allowed. All ideas are written. We have to be, analytics, practical [5].",

Reading is also important at this age. However, making questions is more important. Teachers should choose and formulate questions carefully.

Thorpe categorizes four type of questions [6].

- Summary and defining questions;

- Analytical questions;

- Assuming questions;

- Evaluation question.

Reading a literary piece is treated as a piece, which produces questions. After reading a section, students have questions, and this is about 'exploring their horizons'. In this way, teachers invite students to ask questions, in discussion and in writing. All questions focus on the relationships, feelings, experiences of human beings that are understood through the text but not stated openly. Children at this age tend to use compensation strategies help them overcome limitations in existing knowledge, such as guessing the meaning of unknown words while reading or listening and using gestures in speaking and synonym in writing [1]. 


\section{CONCLUSION}

To sum up, I can say that teaching a foreign language at different ages is a challenge. An ongoing process asks for determination and passion. Children of different ages are motivated in different ways. It is of real importance to find the right strategies according to each age group to encourage students to talk in a foreign language. Children aged 5-7 use memory strategies more frequently than older students do. Role-playing is found to be more productive with 10-15 age group. Children use receptive strategies such as repetition and memorization first. Atmosphere plays an important role in learning a foreign language with all the ages. When students are comfortable, they feel more as if they want to talk in a foreign language and they are not afraid of making mistakes or that others would judge them.

Of course, it is natural to have difficulty learning a foreign language. Teachers should keep track of where students are struggling and help students find ways to address them.

In fact, it is up to the teacher to choose and decide which techniques are best to use in a class.

\section{REFERENCES}

[1] Oxford, Rebecca. (1990). Language learning strategies: What every teacher should know. New York, NY: Newbury. House Publishers.

[2] Daniels, Harvey, and Marilyn Bizar, Methods That Matter, York, Maine: Stenhouse, 1998.

[3] Bruner, Jerome, the Process of Education, New York: W. W. Norton, 1965

[4] Brookfield, S. 1987, Developing Critical Thinking, Challenging Adults to Explore.

[5] Boostrom, R. 1994, Developing creative and critical Thinking.

[6] Thorpe, J. 1992, Methods of inquiry programme.

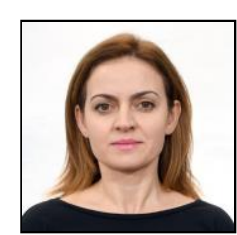

Daniela (Dilo) Gordi was born on $9^{\text {th }}$ April 1980 in Fier, Albania. She graduated English Language at "Eqerem Cabej" University of Gjirokastra, Albania. She received her Master Degree in University of Foreign Languages, in Tirana, Albania.

She started working in 2006 as a part time English Lecturer at University of Foreign Languages in Tirana, Albania. From 2007 -2009 she worked as an English Teacher in a private high school in Tirana.

In 2009 she founded her center of foreign languages in Tirana where she has been teaching English during these times with all school children, starting from elementary to high school students. In 2009 she started working as a part time Lecturer at University of Economics in Tirana where she has been teaching business English since then.

Now she manages and is the principal of her own center of foreign languages and is currently working on her $\mathrm{Ph}$. D thesis in the University of Foreign Languages in Tirana, Albania. 